\title{
SUSTENTABILIDADE AMBIENTAL EM ESTÁDIOS DE FUTEBOL: A PERCEPÇÃO DO TORCEDOR
}

\author{
Vinicius Vizorek Rodrigues
}

Bacharel em Administração. Centro Universitário Metodista - IPA.

\section{RESUMO}

Os grandes eventos esportivos mundiais exigem dos países em desenvolvimento a adequação à regras pré estabelecidas pelos organismos internacionais que regulam estes eventos, como a FIFA (Federação Internacional de Futebol Associado) e o COI (Comitê Olímpico Internacional), que por sua vez buscam um melhor desempenho ambiental dos países sede, com vistas ao desenvolvimento sustentável. Neste contexto esta pesquisa objetivou verificar se a sustentabilidade dos estádios de futebol é percebida pelos torcedores de dois grandes clubes de Porto Alegre. Como objetivos específicos se buscou descrever as ações de sustentabilidade ambiental nos estádios de futebol dos dois principais times de Porto Alegre; verificar a percepção de um grupo de torcedores sobre as ações de sustentabilidade ambiental desenvolvidas em dois estádios de futebol de Porto Alegre; e verificar se as ações de sustentabilidade ambiental agregam valor a marca do clube na percepção dos torcedores de dois clubes de Porto Alegre. Como referencial teórico que deu base à pesquisa, foram revisados conceitos que abrangem as ações de sustentabilidade ambiental na construção civil e as certificações ambientais da área; o marketing e o marketing verde; a gestão esportiva; o marketing esportivo; e o valor das marcas. A pesquisa se baseou em uma metodologia documental e quantitativa, onde a documental buscou descrever as ações de sustentabilidade ambiental por meio de visitas técnicas aos estádios de futebol dos clubes de Porto Alegre e sites destes clubes. A pesquisa quantitativa foi realizada um questionário que foi respondido pelos torcedores dos dois clubes de Porto Alegre, este questionário foi feito pelo Google formulário, de fácil acesso. Se percebeu que os torcedores têm o interesse em saber e acreditam ser necessário que o seu clube adote medidas sustentáveis ambientais nos estádios, e que os clubes divulgam estas ações, mas 
a divulgação destas ações sustentáveis não é tratada com relevância para os torcedores dos times de futebol.

PALAVRAS-CHAVE: Sustentabilidade. Marketing verde. Futebol.

Percepção do torcedor.

\section{ENVIRONMENTAL SUSTAINABILITY IN FOOTBALL STADIUMS:PERCEPTION OF THE BENDER}

\section{ABSTRACT}

The major world sporting events require developing countries to comply with the rules established by the international bodies that regulate these events, such as FIFA (International Federation of Associated Football) and the IOC (International Olympic Committee), which in turn seek a better environmental performance of host countries with a view to sustainable development. In this context, this research aimed to verify if the sustainability of the soccer stadiums is perceived by the fans of two great clubs of Porto Alegre. As specific objectives we sought to describe the actions of environmental sustainability in the football stadiums of the two main teams in Porto Alegre; to verify the perception of a group of fans about the actions of environmental sustainability developed in two soccer stadiums of Porto Alegre; and to verify if the actions of environmental sustainability add value to the club brand in the perception of the fans of two clubs of Porto Alegre. As a theoretical reference that gave base to the research, concepts were revised that include the actions of environmental sustainability in the civil construction and the environmental certifications of the area; marketing and green marketing; sports management; sports marketing; and the value of the marks. The research was based on a documental and quantitative methodology, where the documentary sought to describe the actions of environmental sustainability through technical visits to the football stadiums of Porto Alegre clubs and sites of these clubs. The quantitative research was carried out a questionnaire that was answered by the fans of the two clubs of Porto Alegre, this questionnaire was made by Google form, easily accessible. It has been realized that fans have an interest in knowing and believe that it is necessary for their club to adopt sustainable environmental measures at the stadiums, and that the clubs publicize these actions, but the dissemination of these sustainable actions is not treated with relevance to the fans of the teams. soccer.

KEYWORDS: Sustainability. Green marketing. Soccer. Perception of the supporter. 


\section{INTRODUÇÃO}

Com a expansão de grandes eventos esportivos para países em desenvolvimento, como as Copas do Mundo em 2010 na África do Sul e em 2014 no Brasil, as políticas por edificações ecológicas ficaram cada vez mais em evidência, uma vez que para os clubes de futebol, os seus estádios demandam grandes obras de infraestrutura que, inevitavelmente, impactam o meio ambiente (MASCARENHAS; BIENENSTEIN; SÁNCHEZ, 2011). Abordando o tema, Pereira (2013) expõe que projetos de novas arenas são, em geral, exportados da Europa e dos Estados Unidos para o resto do mundo, contrapondo as noções locais de respeito e sustentabilidade ambiental.

Somente em 2006, com os preparativos para a Copa do Mundo da Alemanha é que a Federação Internacional de Futebol Associado (FIFA), a instituição que supervisiona diversas federações, confederações e associações relacionadas com o futebol, e seus parceiros introduziram políticas ambientais, através do Programa Green Goal ${ }^{\mathrm{TM}}$, que busca a redução das emissões de $\mathrm{CO}_{2}$, na organização e disseminação de Copas ambientalmente mais sustentáveis (FIFA, 2007).

Para a Copa do Mundo de 2014, sediada no Brasil, a FIFA exigiu que todos os estádios construídos onde ocorressem os jogos, fossem certificados pela Leadership in Energy and Environmental Design (LEED). Este certificado, adotado pela instituição máxima do futebol, consiste em um sistema internacional para certificação ambiental de edificações norte americano, criado no ano 2000, pelo United States Green Building Council (USGBC). O LEED é utilizado em diversos países do mundo, e objetiva certificar projetos que foram construídos com estratégias que melhoram o desempenho da sustentabilidade ambiental. Especificamente nos estádios sedes da Copa do Mundo de 2014, foram avaliadas questões como: uso racional da água; eficiência energética; redução, reutilização e reciclagem de materiais e 
recursos; qualidade dos ambientes internos da edificação; e espaço sustentável (OLIVEIRA; SOUZA; GALVÃO, 2014).

A gestão ambiental interfere diretamente na gestão das marcas, pois as organizações, entre elas os clubes de futebol, estão se adequando para fazer a diferença nas localidades onde operam, buscando novas práticas responsáveis, atingindo novos mercados e consumidores, por conseguinte, contribuindo para um melhor comprometimento com o meio ambiente. Com isso, a marca obterá uma valorização, pois agregará um diferencial em relação aos concorrentes (SOLTO, 2011). A preocupação com o bom desempenho ambiental de uma organização vem ao encontro de Keller e Machado (2006), quando os autores afirmam que as organizações perceberam que seus ativos mais valiosos são os nomes de marca associados a seus produtos ou serviços. Assim, o futebol brasileiro se adequou a este pensamento, criando o marketing esportivo, se espelhando em clubes de sucesso como os europeus, lançando novos produtos como a terceira camiseta, trazendo jogadores renomados, construindo suas arenas para grandes públicos, por conseguinte, fortalecendo a imagem de sua marca. Segundo Poit (2006) o marketing esportivo trata o esporte como um produto e este produto, que é uma elaborada atividade humana, tem demonstrado uma indiscutível vocação comercial, neste sentido esta pesquisa explorou a relação entre as edificações sustentáveis de dois clubes de futebol e a percepção dos seus torcedores sobre estas ações de sustentabilidade.

Neste contexto se define o objetivo geral deste trabalho como: Verificar se a sustentabilidade dos estádios de futebol é percebida pelos torcedores dos dois principais clubes de Porto Alegre. Para que o mesmo fosse alcançado foram necessárias etapas intermediárias, os objetivos específicos, que foram: descrever as ações de sustentabilidade ambiental nos estádios de futebol dos dois principais times de Porto Alegre; verificar 
a percepção de um grupo de torcedores sobre as ações de sustentabilidade ambiental desenvolvidas em dois estádios de futebol de Porto Alegre; e verificar se as ações de sustentabilidade ambiental agregam valor a marca do clube na percepção dos torcedores dos dois principais clubes de Porto Alegre.

A presente pesquisa se justifica frente a exigências da FIFA, que mantém uma lista de pré-requisitos aos quais os estádios devem se adequar para terem direito a sediar eventos como a Copa do Mundo e outros jogos de futebol internacionais (PEREIRA, 2013). Estas exigências estão relacionadas às questões de responsabilidade socioambiental, temas como o aquecimento global, a conservação ambiental e o manejo sustentável e receberam destaque durante a última edição da Copa do Mundo FIFA de 2014. No século XXI, esta temática ambiental se tornou uma preocupação constante e explícita das organizações, se incluindo ai a entidade máxima do futebol mundial (PEREIRA, 2013).

\section{REFERENCIAL TEÓRICO}

Neste item se apresentam os principais conceitos referentes ao assunto em questão, a partir de um melhor entendimento sobre um tema contemporâneo, como as ações de sustentabilidade ambiental na construção civil e as certificações ambientais da área; o marketing e o marketing verde; a gestão esportiva; o marketing esportivo; e o valor das marcas.

As ações de sustentabilidade ambiental na construção dos estádios e arenas

A sustentabilidade é um termo que busca definir ações para complementar as necessidades humanas, sem comprometer as gerações que estão por vir. A sustentabilidade está ligada ao desenvolvimento econômico e material com respeito ao o meio ambiente, usando os elementos da natureza, buscando 
manter estes materiais sem prejudicar a natureza (DIAS, 2015). Neste contexto é inegável o impacto gerado pela construção civil ao meio ambiente, assim arquitetos, engenheiros e profissionais da área, buscaram alternativas para diminuir tais impactos, incorporando nas grandes obras melhores níveis de qualidade ambiental em seus projetos (PEREIRA, 2013).

O conselho Brasileiro de Construção Civil (CBCC) e a Associação Brasileira de Escritórios de Arquitetura (AsBEA), criaram práticas para o melhoramento dos projetos no quesito ações sustentáveis, como por exemplo, aproveitamento ao máximo das condições naturais das construções, utilizar o mínimo do terreno e integrar a obra ao ambiente natural, reduzir impactos no entorno, implantar formas sustentáveis da obra, reduzir, reutilizar, reciclar e dispor corretamente os resíduos sólidos, entre outros. Estes exemplos de princípios da sustentabilidade, da construção civil, nem sempre são vistas com bons olhos, pois geralmente, as empresas preocupam-se somente com a parte econômica (PEREIRA, 2013).

Relacionando a sustentabilidade ambiental as obras civis, Teodoro (2011) expõe que o objetivo da sustentabilidade não é manter o meio ambiente intocado, sendo que o grande propósito da sustentabilidade nas empresas da área é minimizar os efeitos da construção no ambiente. Ainda com relação a sustentabilidade na construção civil Agopyan, John e Goldemberg (2011) esclarecem que os impactos ambientais da construção civil envolvem uma enorme cadeia produtiva, que inclui desde a extração de matérias primas; produção e transporte de materiais e componentes; concepção e projetos; execução (construção), práticas de uso e manutenção e, ao final da vida útil, a demolição /desmontagem, além da destinação de resíduos gerados ao longo da vida útil. Agopyan, John e Goldemberg (2011) também se utilizam do conceito de tripé da sustentabilidade de Elkington (2012) no contexto da cons- 
trução civil: Conforme Agopyan, John e Goldemberg (2011), o tripé da sustentabilidade Ambiente-Economia-Sociedade, é a base pela qual se define se todas as partes saem ganhando em um projeto de edificação, o que o torna uma edificação sustentável. Assim sendo, se observa que existem prioridades para tornar uma construção sustentável, que são sintetizadas por Teodoro (2011) conforme o Quadro 1:

\section{Quadro 1 - Prioridades para construção verde ou sustentável}

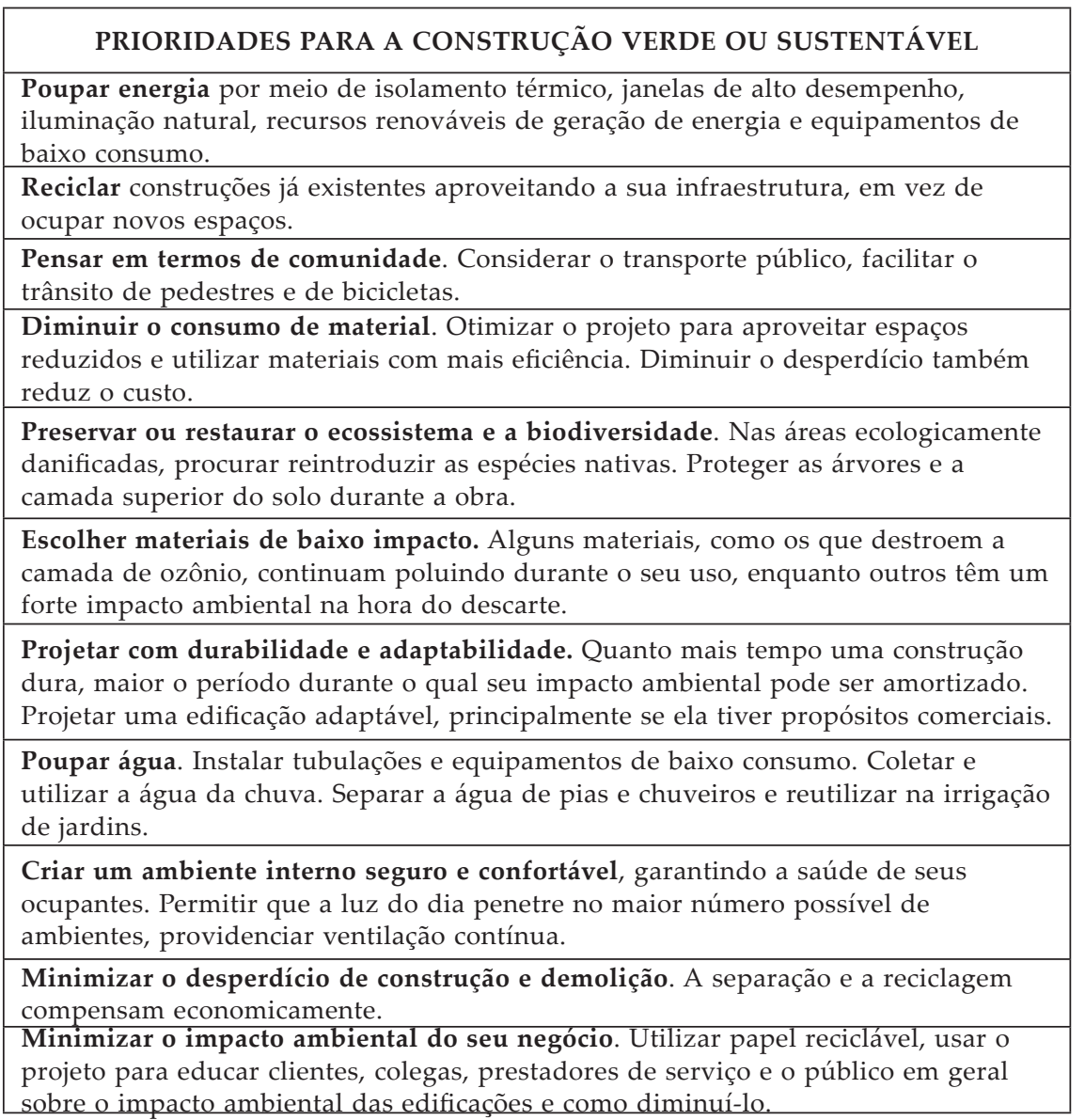

Fonte: Teodoro (2011) adaptado pelo autor 
Muitas destas ações podem ser claramente mensuradas, com consumo de água e energia, e o desempenho de das edificações com relação a estes e outros itens podem resultar em certificações ambientais, como destaca Pereira (2013), assunto que será abordado a seguir.

\section{Certificações ambientais na construção civil}

Quando um empreendimento apresenta medidas sustentáveis, e que o projeto tenha no seu ciclo preocupações socioambientais, existe a possibilidade deste empreendimento buscar um certificado ambiental (PEREIRA, 2013). Barbieri (2009) destaca que tais certificações ou selos são uma forma idônea e de fácil identificação por parte dos clientes, do compromisso com a sustentabilidade ambiental da empresa. estas certificações tem como principal objetivo mostrar para o público de uma determinada organização, que tal produto ou serviços se utilizam de procedimentos ecologicamente corretos, que não agridem ao meio ambiente, com a captação consciente de matéria-prima. A International Organization for Standardization (ISO) 14000 subdivide os rótulos ambientais, ou selos verdes, em três tipos conforme Barbieri (2007):

Rótulos tipo I são aqueles criados por entidades independentes ou de terceira parte aplicáveis aos produtos que apresentam certos padrões ambientais aplicados a sua categoria. [...] O rótulo tipo II, objeto da norma ISO 14021, refere-se à reivindicação de autodeclaração, sem certificação independente ou com uma certificação feita por produtores, comerciantes, distribuidores ou por quem se beneficie de tal reivindicação, para informar aos consumidores as qualidades ambientais de seus produtos ou serviços. [...] As autodeclarações mais comuns são os símbolos de reciclagem estampados em produtos e embalagens. [...] Os rótulos do tipo III, que trazem informações sobre dados ambientais de produtos, quantificados de acordo com um conjunto de parâmetros previamente selecionados e baseados na avaliação do ciclo de vida (BARBIERI, 2007, p. 165). 
Entre os diversos rótulos ambientais, se destacam aqueles que são certificados por terceiros, que alcançam credibilidade no mercado. Conforme Macedo (2014), o principal selo de construção sustentável é o certificado LEED, certificação ambiental que se tornou referência para que diretrizes ambientais fossem adotadas e avaliadas pelas empresas, em seus projetos está o sistema de certificação LEED desenvolvido em 1998, pelo United States Green Building Concil (USGBC). (PEREIRA, 2013)

O LEED é uma certificação baseada na harmonização; na ponderação de créditos em função do impacto ambiental e da saúde humana; e na regionalização. Os itens com maior importância neste sistema de avaliação são a eficiência energética e a redução da emissão de $\mathrm{CO}_{2}$, e o selo certifica edifícios a partir de uma lista de pré-requisitos e créditos, possuindo quatro níveis concedidos de acordo com a pontuação alcançada pela edificação: Certificado, Prata, Ouro e Platina (USGBC, 2012). Para obter a certificação LEED é preciso obedecer a diversos critérios estabelecidos a partir de uma lista de oito dimensões a serem avaliadas nas edificações. Todas elas possuem pré requisitos, que são obrigatórios, e créditos, que são recomendações que, quando atendidas, garantem pontos a edificação. O nível da certificação é definido, conforme a quantidade de pontos adquiridos, podendo variar de 40 pontos, nível certificado a 110 pontos, nível platina.

Os pré-requisitos são definidos pela USGBC (2012, paginação irregular) como as "ações obrigatórias em qualquer empreendimento que busca a certificação. Não cumprindo um dos diversos pré-requisitos, impossibilita o empreendimento a receber a certificação." Aos pré-requisitos se somam os créditos, que segundo a USGBC (2012, paginação irregular) são "ações que o LEED sugere, sempre focadas em performances de desempenho. A medida que o empreendimento assume tal ação, recebe uma pontuação." 
Os pré-requisitos, os quais possuem pontuações diferentes, examinados são: localização e transportes; espaço sustentável; eficiência no uso da água; eficiência energética; redução reutilização e reciclagem de materiais; qualidade ambiental interna; inovação e processos; e atendimento as necessidades locais.

\section{O Marketing Verde}

Durante a segunda metade do século $\mathrm{XX}$, ocorreu uma enorme demanda de consumo, marcada pela utilização e o desperdício, com o descarte de itens mais antigos na troca por novos mais sofisticados, um momento na história em que as pessoas passaram ser chamadas de consumidores (DIAS, 2009). De forma concomitante, as preocupações com o meio ambiente estão na rotina das atividades humanas, e assim o ambiente natural está servindo de objeto de análise. Inclui-se o marketing nesta análise, pois as sociedades tornaram-se mais sensíveis perante o meio ambiente, há a necessidade de assumir novos comportamentos em relação aos temas ambientais (DIAS, 2009).

O marketing verde procura equilibrar a produção com o faturamento das organizações perante o mercado global, criando uma abordagem socioambiental mais ampla, com isso requer que os conceitos fundamentais do marketing sejam reavaliados (DIAS, 2009). O marketing verde é derivado do marketing básico que visa atender as necessidades de consumidores que buscam um comportamento ecológico, por se preocuparem com o meio ambiente. Nesta ótica, consiste na aplicação da promoção, da produção e na recuperação de produtos que causam dano ao meio ambiente (BOONE; KURTZ, 2001).

No mundo globalizado, que causou o aumento do consumo de recursos naturais, as pessoas se tornaram consumidoras, e com isso as organizações adotaram medidas sustentáveis. 
Diversas empresas utilizaram o marketing verde como estratégia e vantagem competitiva para conquistar o mercado e conscientizar as pessoas para praticar ações sustentáveis (GUIMARÃES; VIANA; COSTA, 2015).

Nascimento, Lemos e Mello (2008), ressaltam que o gestores perceberam que, além de necessária, a consciência ambiental também é lucrativa. $\mathrm{O}$ marketing verde não se limita à promoção de produtos ambientalmente corretos, mas ajuda na promoção da imagem das empresas que, para serem consideradas sustentáveis, devem incorporar as questões ambientais em todas as suas atividades.

\section{Marketing Esportivo}

Segundo Keller e Machado (2006), o marketing esportivo tornou-se muito sofisticado nos últimos anos, empregando técnicas tradicionais dos produtos de consumo. Não se contentando mais com permitir que os registros de vitórias e derrotas ditassem os resultados financeiros, muitas equipes esportivas estão utilizando uma combinação criativa de propaganda, promoções, patrocínio, marketing direto e outros tipos de comunicação. Os autores adicionam a esta ideia quando expõem que:

Desenvolvendo conhecimento de marca, imagem e fidelidade, essas marcas conseguem atingir objetivos de receita independentemente do desempenho real de seu time. Símbolos e logotipos, em particular, tornam-se importantes fontes de receita dos esportes profissionais, mediante a acordos de licenciamento (KELLER; MACHADO, 2006, p.19).

Na concepção de Kotler e Gertner (2004), uma marca poder ser considerada como ferramenta para o profissional do marketing para a diferenciação dos produtos oferecidos no mercado que são facilmente copiadas e dificilmente diferenciadas pelo consumidor. As marcas podem ser compradas e 
vendidas, alugadas e franqueadas. A gestão de marcas deixou de ser apenas uma ferramenta e tem mostrado um importante segmento no marketing, com modernas práticas, com objetivos de consolidação da marca frente ao mercado, disputando com várias empresas do mesmo segmento, tornando-se extremamente competitivo.

O marketing esportivo é o processo de elaboração de um produto, formação de preço, promoção e distribuição de um produto esportivo, criando assim o desejo ou a satisfação dos compradores e realizar os objetivos da organização (PITTS, STOTLAR, 2002).

Na década de 1980, os clubes eram vistos como meios de divulgação de outras marcas como, Coca-Cola, Parmalat, Fiat, entre outras, mas a partir da década de 1990, os clubes também passaram a ser observados como marcas de maneira que os produtos dos clubes fossem produzidos e comercializados em grande proporção, gerando uma receita considerável (CHATAIGNIER, 2004). Neste contexto se observa que o marketing esportivo está se profissionalizando, tornando possível a realização de grandes eventos que demandam grandes públicos, vendendo cada vez mais produtos ligados ao esporte, beneficiando-se da paixão das pessoas pelo esporte, por conseguinte, os clubes aumentaram suas receitas, assim tendo como sustentar altos salários dos atletas (CHATAIGNIER, 2004).

O marketing esportivo é a função mais importante dos negócios esportivos, devido ao crescimento da indústria do esporte, que não dá sinais que um dia irá acabar. Com este crescimento, cada vez mais a concorrência cresce, e com isso, cada produto ou organização esportivo, significa concorrência. Concorrência significa que um negócio compete com outro na busca de conquistar o dinheiro do consumidor. Todo o negócio esportivo deve adotar o marketing esportivo na sua gestão, pois assim a organização se guiará pelo marketing esportivo (PITTS, STOTLAR, 2002). 
O Valor da Marca

Uma marca é um nome diferenciado e/ou símbolo, como um logotipo, marca registrada, ou desenho de embalagem, com isso, os bens e serviços são identificados para os vendedores e diferenciados dos concorrentes. Assim a marca sinaliza e identifica ao consumidor a origem dos produtos para que seja diferenciado dos concorrentes que oferece produtos idênticos (AAKER, 1998).

O valor da marca é estabelecido devido ao fato de que hoje é mais difícil construir marcas do que há algumas décadas atrás. O custo de distribuição e de propaganda é muito alto. Aaker (1998) destaca que o brand equity é um conjunto de ativos e passivos ligados a uma marca, seu nome e seu símbolo, que se subtraem do valor proporcionado por um produto ou serviço para uma empresa e/ou para os consumidores dela. O autor complementa esta ideia quando diz:

Para que certos ativos e passivos determinem o brand equity, eles devem estar ligados ao nome e símbolo da marca. Se o nome da marca ou seu símbolo for mudado, alguns ou todos os ativos ou passivos poderão ser afetados, e mesmo perdidos, embora parte deles possam ser desviados para um novo nome e símbolo. Os ativos e passivos nos quais o brand equity se baseiam vão diferir de contexto a contexto. Contudo, podem, de forma prática, ser agrupados em cinco categorias, lealda à marca, conhecimento do nome, qualidade percebida, associação à marca em acréscimo à qualidade percebida, e por fim, outros ativos do proprietário da marca - patentes, trademarks, relações com os canais de distribuições etc. (AAKER, 1998, p. 16).

O brand equity, pode dar destaque a novos programas para atrair novos consumidores e reconquistar antigos; As quatro últimas categorias podem ressaltar a lealdade à marca; Pode proporcionar menor utilização de promoções; possibilita uma plataforma para o crescimento via extensões da marca; e por fim, pode dar força ao canal de distribuição (AAKER, 1998). 
A principal característica do brand equity é a lealdade à marca que é a base dos consumidores, mas se os compradores de determinado produto são indiferentes e compram segundo características, preço e conveniência, é porque há pouco brand equity. Se por outro lado, continuam a comprar a marca mesmo que haja concorrentes com características superiores, preço e conveniência é porque existe valor na marca (AAKER, 1998).

A lealdade à marca que é um dos pilares do marketing é uma medida que indica a ligação do consumidor com a marca. Conforme a lealdade da marca aumenta é quase improvável que este consumidor vá buscar outra marca com as mesmas características do produto da marca que este consumidor já é leal. Isto é um indicador do brand equity claramente ligado aos lucros futuros (AAKER, 1998).

O desafio do Marketing na construção de uma marca é garantir que os consumidores tenham melhor proveito de produtos e serviços e que o Marketing consiga criar estruturas desejadas de conhecimento da marca para um comprador em potencial (KOTLER; ARMSTRONG, 2006). O conhecimento da marca é a capacidade de um comprador potencial reconhecer uma marca como integrante de certa categoria de produtos (AAKER, 1998).

A qualidade percebida é todo o conhecimento que o consumidor tem de qualidade geral que um determinado produto ou serviço tem, ou seja, é o conhecimento dos consumidores perante determinada marca (AAKER, 1998). Ainda de acordo com Aaker (1998) a qualidade percebida não pode ser determinada objetivamente, pois se trata do conhecimento dos consumidores, e também está envolvido o julgamento sobre o que seja importante para o comprador. A qualidade percebida é um ativo intangível, pois se trata de um sentimento do consumidor sobre uma marca, contudo, o comprador se baseará nas características do produto ou serviço, as quais a 
marca esteja conectada, como confiabilidade e desempenho (AAKER,1998).

Uma associação de marca está ligada a uma imagem na memória do comprador. Assim como o McDonald's poderia estar ligado a uma personalidade, um segmento de consumo, sentimento, vontade de se divertir, as características do produto, serviço, entre outros (AAKER, 1998). Esta associação não somente existe como também gera uma força com uma marca quando for baseada em muitas experiências. Será mais forte se for apoiada por outras marca (AAKER,1998).

\section{METODOLOGIA}

Esta pesquisa buscou verificar se a sustentabilidade dos estádios de futebol é percebida pelos torcedores dos dois principais clubes de Porto Alegre, sendo assim, no que diz respeito aos objetivos, a pesquisa caracteriza-se como descritiva, que Roesch (2009) é aquela pesquisa que busca é obter informações sobre uma determinada população. A abordagem do problema se deu de forma quantitativa, através de uma procedimento de levantamento de campo que se caracterizou pelo questionamento direto às pessoas, desejando conhecer o comportamento ali vivido, com isso, é solicitado as informações a cerca do problema estudado.

A pesquisa foi aplicada em dois clubes de futebol, onde um se encontra na Zona Norte, denominado de Time A, e o outro na Zona Sul da cidade de Porto Alegre, denominado de Time B. Se esclarece que o Time A conta com 6 milhões de torcedores e o Time B com 5,6 milhões de torcedores, caracterizando uma população inicial de 11,6 milhões de torcedores em todo o país (FOX SPORTS, 2017), sendo necessário delimitar uma amostra. Na opinião de Marconi e Lakatos (2010, p. 147) "a amostra é uma parcela convenientemente selecionada do universo (população); é um subconjunto do universo". A partir

ReMAS • Revista Metodista de Administração do Sul, v. 2, N. 2, 2017 
destas informações foi possível caracterizar uma amostra de 271 pessoas, aplicando-se o cálculo amostral com um nível de confiança de $90 \%$ e um erro amostral de $5 \%$.

Para alcançar esta amostra o pesquisador disponibilizou um questionário do GoogleDocs, pacote de aplicativos do Google, onde buscou totalizar os 271 respondentes. A partir disto o autor divulgou em redes sociais a pesquisa, solicitando a participação dos seus contatos e que os mesmo indicassem outros respondentes em uma metodologia similar a snowball, entretanto findo o prazo estabelecido, entre 20 de março e 30 de abril de 2017, não foi possível alcançar os 271 respondentes. Frente a limitação do prazo, a pesquisa foi encerrada com participação de 220 torcedores, sendo 113 do time A e 107 do time $\mathrm{B}$, um número próximo ao ideal. Cabe ressaltar que esta é uma amostragem não probabilística, já que foi utilizada uma rede de contatos. Conforme Gil (2008, p. 94) uma amostra "consiste em selecionar um subgrupo da população que, com base nas informações disponíveis, possa ser considerado de toda a população".

No levantamento dos dados também foi utilizada a pesquisa documental e observação, realizadas em visita guiada aos estádios. As visitas se realizaram respectivamente no dia 26 de março de 2017, durante uma hora e meia no estádio do time A; e no dia 13 de maio de 2017, em uma vista de uma hora e meia ao estádio do time B quando foram coletados os dados e registradas em diário de campo os questionamentos dirigidos aos guias de ambas as visitas, sendo que o pesquisador não se identificou como tal.

Para a pesquisa quantitativa foi utilizado um questionário com estrutura Likert, que verifica o nível de concordância do sujeito com diversas afirmações que expressem algo vantajoso ou desvantajoso em relação a um objeto psicológico (LIKERT, 1976). O questionário contou com 14 questões coletadas a 
partir de técnica snowball. Esta técnica é conhecida no Brasil como "amostragem em Bola de Neve", ou "Bola de Neve" ou, ainda, como "cadeia de informantes" (BALDIN; MUNHOZ, 2011). É uma forma de amostra não probabilística utilizada em pesquisas sociais onde os participantes iniciais de um estudo indicam novos participantes, que por sua vez indicam novos participantes e assim sucessivamente, até que seja alcançado o objetivo proposto (o "ponto de saturação"). $\mathrm{O}$ "ponto de saturação" é atingido quando os novos entrevistados passam a repetir os conteúdos já obtidos em entrevistas anteriores, sem acrescentar novas informações relevantes à pesquisa. (BALDIN; MUNHOZ, 2011, p. 332).

Após a coleta, foi realizada uma análise estatística descritiva que para Sincich $(2009$, p. 3) é aquela que utiliza métodos numéricos e gráficos para "detectar padrões em um conjunto de dados, para resumir a informação revelada em um conjunto de dados e para apresentar a informação em uma forma conveniente." O desenvolvimento da pesquisa documental ocorreu através da análise de documentos oficiais e reportagens de jornais e revistas sendo que todos os dados forma confrontados com o referencial teórico levantado, permitindo assim as conclusões.

\section{RESULTADOS E DISCUSSÃO DA PESQUISA}

O clube do Time A possuiu ao longo de sua história três estádios de futebol, atualmente está localizado no Bairro Humaitá, em Porto Alegre. Com capacidade para 58.000 pessoas, o atual estádio do Time A foi inaugurado no dia 8 de dezembro de 2012. Avaliada em 700 milhões de reais, a arena do Time A conseguiu um feito inédito aos estádios brasileiros, sendo a primeira a obter o certificado LEED, em reconhecimento ao reduzido impacto ambiental da estrutura. 
O clube do Time B possuiu ao longo de sua história dois estádios de futebol, atualmente está localizado na Avenida Padre Cacique, 891, no bairro Menino Deus, Porto Alegre, as margens do Rio Guaíba. Com capacidade para aproximadamente 51.000 pessoas, o atual estádio do Time B foi inaugurado no dia 06 de abril de 1969, e que passou por uma reforma para ser uma das sedes da Copa do Mundo no Brasil, reforma esta que foi feita entre os anos de 2012 a 2014. Com custo de 300 milhões de reais, o estádio do Time B, com as obras de reforma, recebeu o certificado LEED junto a FIFA, pois foram feitas diversas ações de sustentabilidade ambiental na sua reestruturação, podendo assim sediar jogos em grandes eventos esportivos realizados pela FIFA.

A fim de descrever as ações de sustentabilidade ambiental desenvolvidas nos estádios de futebol dos times A e Time B, foi feita uma visita aos estádios dos times A e B. A partir disto foram percebidas algumas ações sustentáveis que o estádio do Time A adota, como o reaproveitamento da água da chuva para irrigar o gramado, diminuindo assim o consumo de água; a escolha do local de construção do estádio, pois era um terreno bastante degradado e com para receber o estádio, foi recuperado para receber o gramado, entre outras ações que sumarizadas no Quadro 2.

Já no Time $\mathrm{B}$, foi realizada uma reforma com o intuito de se enquadrar aos padrões FIFA exigidos por esta instituição para sediar os jogos da Copa do Mundo de 2014 no Brasil. Esta reforma ocasionou diversas ações de sustentabilidade ambiental e com isso o Estádio adquiriu o certificado LEED. A edificação capta a água da chuva e faz o seu reaproveitamento na irrigação do gramado do estádio e a sua cobertura em politetrafluoretileno (Teflon), que é um material 100\% reciclável, com durabilidade e translúcido, permite mais eficiência da luz solar. As ações sustentáveis da edificação do Time A estão sumarizadas no Quadro 3. 
Quadro 2 - Ações sustentáveis ambientais percebidas na visita ao estádio do time A

\begin{tabular}{|c|c|}
\hline Entorno & $\begin{array}{l}\text { O estádio possui a certificação LEED, sendo assim, } \\
\text { destacam-se as seguintes medidas sustentáveis: prevenção } \\
\text { ativa de poluição na construção, no entorno é percebido } \\
\text { que as vias onde os carros trafegam são formadas } \\
\text { por blocos com espaçamento entre eles de cerca de } 1 \\
\text { centímetro, com a meta de amenizar o uso do asfalto e } \\
\text { a diminuição de alagamentos. Estacionamento com mais } \\
\text { de } 50 \% \text { das vagas cobertas, reduzindo o efeito da ilha de } \\
\text { calor e vagas preferenciais para veículos de baixa emissão } \\
\text { de poluentes e de incentivo a caronistas. }\end{array}$ \\
\hline Água & $\begin{array}{l}\text { A cobertura capta até } 50 \% \text { da irrigação do gramado, que } \\
\text { é automatizada, economizando mais de } 30 \% \text { de água } \\
\text { potável. As águas pluviais captadas, também são utilizadas } \\
\text { nos sanitários. }\end{array}$ \\
\hline Energia & $\begin{array}{l}\text { Há pelo menos } 10 \% \text { de redução de consumo de energia } \\
\text { anual, pois com as luzes de LED em relação a lâmpadas } \\
\text { normais, há uma redução de até } 80 \% \text { de energia, e com } \\
\text { ar condicionados de alta eficiência, mas com baixo nível } \\
\text { de potência. }\end{array}$ \\
\hline Materiais & $\begin{array}{l}\text { Na construção do estádio foi usado aço reciclado em } 50 \% \\
\text { da obra. Os motores dos tratores não tinham substâncias } \\
\text { poluentes, como graxa na lubrificação, foi usada a } \\
\text { tecnologia de magnetismo. Também foi usado o máximo } \\
\text { de materiais regionais, reciclados e certificados. }\end{array}$ \\
\hline Resíduos & $\begin{array}{l}\text { O Estádio conta com áreas permanentes de segregação de } \\
\text { resíduos e promove campanhas de conscientização, para } \\
\text { os torcedores. }\end{array}$ \\
\hline $\begin{array}{l}\text { Conforto } \\
\text { Ambiental }\end{array}$ & $\begin{array}{l}\text { Cobertura na cor branca, de alta refletividade, minimizando } \\
\text { os ganhos com calor e reduzindo a carga térmica da } \\
\text { construção. }\end{array}$ \\
\hline
\end{tabular}

Fonte: Dados da pesquisa. 
Quadro 3 - Ações sustentáveis ambientais percebidas na visita ao estádio do time $B$ e em estudos realizados.

\begin{tabular}{|c|c|}
\hline Entorno & $\begin{array}{l}\text { O estádio possui a certificação LEED, sendo assim, } \\
\text { destacam-se as seguintes medidas sustentáveis: plano } \\
\text { de redução de poluição do solo, com o objetivo de } \\
\text { reduzir a poluição proveniente das atividades na } \\
\text { reforma do estádio, assim controlando a erosão do } \\
\text { solo. Estacionamento exclusivo para veículos menos } \\
\text { poluentes, o piso é de blocos intertravados, ou seja, } \\
\text { com espaçamento de até } 1 \text { centímetro que aumentam } \\
\text { a permeabilidade. Além disso, o estádio se integra de } \\
\text { forma definitiva a orla do Guaíba e ao contexto de } \\
\text { parque ecológico-urbano de Porto Alegre. }\end{array}$ \\
\hline Água & $\begin{array}{l}\text { Sistema de coleta de águas vindas do telhado para } \\
\text { irrigação do gramado e jardins, limpeza de áreas } \\
\text { externas. }\end{array}$ \\
\hline Energia & $\begin{array}{l}\text { Os equipamentos de energia são placas fotovoltaicas } \\
\text { que ao todo são } 16 \text { transformadores distribuídos em } \\
\text { oito subestações, são capazes de fornecer energia a uma } \\
\text { cidade de } 40 \text { mil habitantes, com isso, é possível reduzir } \\
\text { o consumo da rede pública de energia. }\end{array}$ \\
\hline Materiais & $\begin{array}{l}\text { Com a Copa do Mundo de } 2014 \text {, para se obter a } \\
\text { certificação LEED, foi procurado fornecedores de } \\
\text { materiais que já possuíam algum certificado ambiental. } \\
\text { E com, isso gerou uma mudança no mercado de } \\
\text { fornecedores da construção civil em prol de produtos } \\
\text { certificados. O concreto originário das demolições do } \\
\text { estádio foi reaproveitado e transformado em brita para } \\
\text { nova reutilização. }\end{array}$ \\
\hline Resíduos & $\begin{array}{l}\text { O time B já conta com um programa de separação e } \\
\text { reciclagem do lixo e utiliza a grama cortada como adubo } \\
\text { para o relvado, por meio de compostagem. }\end{array}$ \\
\hline $\begin{array}{l}\text { Conforto } \\
\text { Ambiental }\end{array}$ & $\begin{array}{l}\text { A cobertura feita de politetrafluoretileno PTFE, ou } \\
\text { seja, de teflon. Material este com maior durabilidade, } \\
\text { reciclado e translúcido que absorve menos calor e } \\
\text { permite o aproveitamento mais eficiente da luz solar e } \\
\text { das correntes de vento, evitando gastos excessivos com } \\
\text { iluminação artificial e condicionadores de ar. }\end{array}$ \\
\hline
\end{tabular}

Fonte: Dados da pesquisa. 
Aqui cabe ressaltar a opinião de Agopyan, John e Goldemberg (2011) que afirmam que grandes obras resultam em grandes impactos, pois usam maior quantidade de espaço físico e consomem uma grande quantidade de materiais, como água e energia, mas como observado em ambas as construções descritas o propósito da sustentabilidade nas construções consiste em minimizar os efeitos da desta no ambiente. Também se destaca a busca pela certificação LEED em ambas as edificações, o uso destas certificações idôneas permite ao público identificar compromisso com a sustentabilidade ambiental da empresa, como ressalta Barbieri (2009).

Nas duas edificações são perceptíveis várias prioridades para construção verde ou sustentável, citadas por Teodoro (2011), conforme o Quadro 1, entre elas a economia de água, energia e materiais; escolher materiais de baixo impacto; e Criar um ambiente interno seguro e confortável.

Muitas das ações descritas nos Quadros 2 e 3 podem ser claramente mensuradas, como consumo de água e energia, e o desempenho das edificações com relação a estes e outros itens podem resultar em sustentabilidade ambiental, como destaca Pereira (2013).

Para verificar a percepção sobre as ações de sustentabilidade ambiental desenvolvidas nos estádios de futebol dos times A e Time B foi utilizado o instrumento de coleta de dados com perguntas fechadas de escolha simples. As primeiras nove questões traçam um perfil dos pesquisados, verificando se há equilíbrio entre os respondentes dos times foco desta pesquisa. O questionário foi respondido por 220 torcedores, sendo 113 torcedores do Time A e 107 torcedores do Time B.

A primeira questão definiu para qual time torce o pesquisado, sendo constatado que $51,36 \%$ dos torcedores da pesquisa são do Time A e 48,64\% torcedores do Time B. Se verificou que o número de torcedores do Time A é sensivelmente maior que 
o número dos torcedores do Time $\mathrm{B}$, assim como os dados que relatam que a torcida do Time A é maior no do que a do Time B.

As duas questões seguintes buscaram verificar o percentual dos torcedores dos times A e B que efetivamente são sócios, por que estes em geral são mais envolvidos com seus times e podem ter uma e percepção maior sobre as ações de sustentabilidade desenvolvidas nos estádios. Com relação ao Time A, se constata que $64,60 \%$, em um total de 73 entrevistados, não são sócios; e 35,40\%, perfazendo um total de 40 pesquisados, que são efetivamente sócios do sócios do Time A. Com relação ao Time B, 61,7\% (66) dos entrevistados são não sócios, ou seja, a grande maioria, e 38,3\% dos pesquisados (41) é efetivamente sócio do Time B.

A seguir se verificou a faixa etária dos entrevistados. No Time A se constatou que 67,26\% (76 dos entrevistados), ou seja, a grande maioria dos entrevistados, tem idade entre 21 a 30 anos. E no Time B, 45,79\% (49 entrevistados), os torcedores têm idade entre 21 e 30 anos, seguida de 31 a 40 anos com 20,56\% dos entrevistados.

Com relação a escolaridade dos torcedores, se obteve que $49,56 \%$ de entrevistados do Time A que afirmaram ter ensino superior incompleto e $36,28 \%$ ensino superior completo, ou seja, a grande maioria já faz ou fez faculdade em alguma instituição de ensino. Já os entrevistados do Time B compõem de $38,32 \%$ dos entrevistados estão cursando faculdade e $27,10 \%$ já concluíram o curso de formação. Os dados indicam que a maioria dos pesquisados frequentou ou frequenta instituição de ensino superior, indicando uma elevada escolaridade, o que em princípio confere aos pesquisados um maior grau de informação sobre os assuntos relativos a sustentabilidade e ao meio ambiente.

Frente aos resultados se percebe que a amostra está proporcional, há um equilíbrio entre os torcedores dos times $\mathrm{A}$ e 
B, que a maioria destes torcedores, com a mesma proporção em ambos os times, não é sócio. Estes torcedores são jovens, na maioria moradores de Porto Alegre, ou seja têm proximidade às construções pesquisadas e têm escolaridade alta, portanto reúnem condições e informações para perceber a sustentabilidade ambiental em seus times.

A próxima etapa da pesquisa abordou, através de questões utilizando a escala de Likert, a percepção dos torcedores sobre a sustentabilidade em seus times. Aqui o autor fez um recorte sobre os sócio-torcedores, então os gráficos estão duplicados: no primeiro gráfico será apresentada a visão geral da amostra, torcedores de uma forma geral e sócios; no segundo gráfico de cada uma das assertivas propostas estará exposta a percepção exclusivamente dos sócios. Este detalhe buscou identificar se os sócios, em geral pagantes, têm um conhecimento ou preocupação maiores com o bom desempenho ambiental de seus times.

A primeira assertiva desta etapa verificou se o torcedor percebe a preocupação do seu time com o meio ambiente, com as repostas apresentadas no Gráfico 1 .

Gráfico 1 - Vejo que meu clube se preocupa com o meio ambiente.

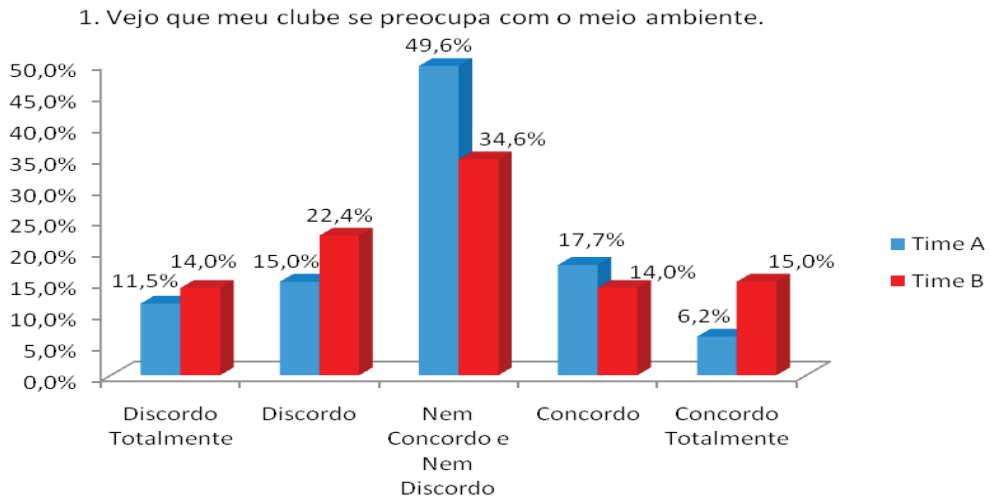

Fonte: Dados da pesquisa. 
Nas afirmações dos torcedores do Time A se observa que $49,6 \%$ dos pesquisados nem concordam e nem discordam sobre este tema, ou seja, são imparciais na afirmação. Quanto aos torcedores do Time B, o resultado foi diferente, com 14\% dos pesquisados que discordam totalmente e $22,4 \%$ que discordam, sendo que a soma dos que discordam totalmente e discordam sobre o tema, chega a $36,4 \%$, superando os que nem discordam e nem concordam que resultou em $34,6 \%$ no Time A. Isso revela que boa parte da torcida dos dois clubes acredita que os seus clubes ainda não se preocupam com o meio ambiente. Neste contexto os dados divergem em parte ao exposto por Dias (2009) que afirma que à medida que as pessoas tornam-se mais sensíveis em relação ao meio ambiente, há a exigência por parte das organizações de assumir novos comportamentos quanto a nova realidade, a do contexto verde.

Na sequencia da pesquisa, se propôs uma afirmação que aborda se o torcedor gosta de saber que o seu clube adota medidas sustentáveis nos estádios (GRÁFICO 2). Os dados do Gráfico 2 mostram que a grande maioria dos torcedores dos times A e Time B, somando 59,3\% e 55,1\% respectivamente, concordam e concordam totalmente com a assertiva, que gostam de saber que seu clube adota medidas sustentáveis nos estádios.

Em relação aos sócios do Time A e Time B, se observou que 55\% dos torcedores do Time A e 58,54\% do Time B, gostariam de saber que o clube adota medidas sustentáveis em seu estádio. Estes resultados permitem supor que os torcedores gostariam de interagir melhor com o meio ambiente e saber que seu clube adota medidas ambientalmente sustentáveis em seus estádios. Poderia ser mais bem explorada esta questão por parte dos dois clubes de Porto Alegre. 
Gráfico 2 - Gosto de saber que meu clube se preocupa com o meio ambiente.

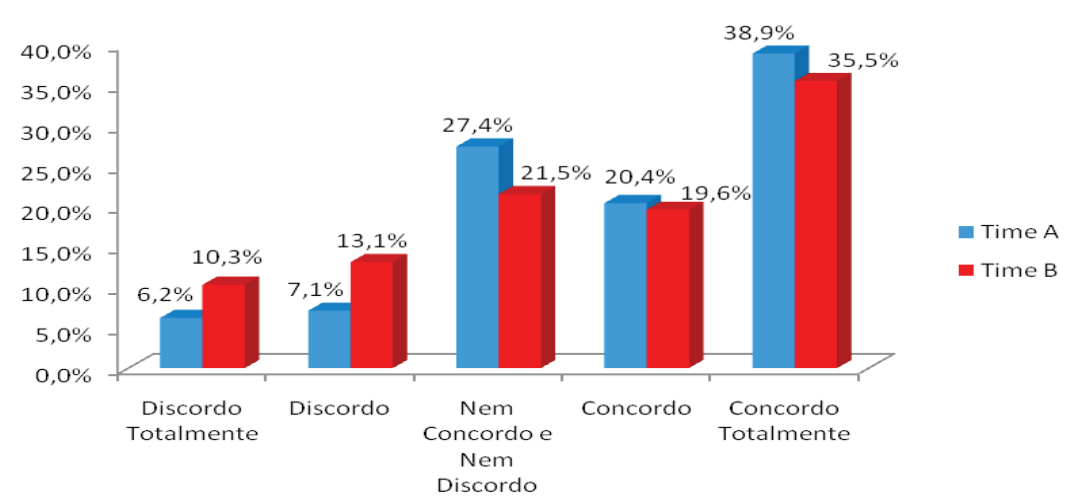

Fonte: Dados da pesquisa.

A afirmação seguinte buscou identificar se os torcedores acreditam que é necessário que os clubes de futebol adotem medidas sustentáveis nos estádios, com os dados apresentados no Gráfico 3. Nas afirmações dos torcedores do Time A, se constatou que $73,5 \%$ (83), ou seja, a grande maioria dos pesquisados concordam totalmente que é necessário que os clubes de futebol adotem medidas sustentáveis nos estádios; frente a $18,6 \%$ (21) que concordam, 7,1\% (oito) que nem concordam e nem discordam, e apenas um entrevistado, ou seja, 0,9\% que discorda desta afirmação.

Já no Time B, o Gráfico 3 apontou que 49,5\% (53) dos pesquisados acreditam ser necessário que os clubes de futebol adotem medidas sustentáveis nos estádios, e 14\% (15) que concordam. Através destas respotas se pode concluir que a grande maioria concorda ou concorda totalmente que é necessário que os clubes de futebol adotem medidas sustentáveis nos estádios, resultando em $63,5 \%$ (68) dos pesquisados. Portanto, os torcedores dos times A e B, em sua grande maioria, acreditam que seus clubes devem aderir a esta nova realidade, a sustentabilidade ambiental. 
Gráfico 3 - É necessário que os clubes de futebol adotem medidas sustentáveis nos estádios.

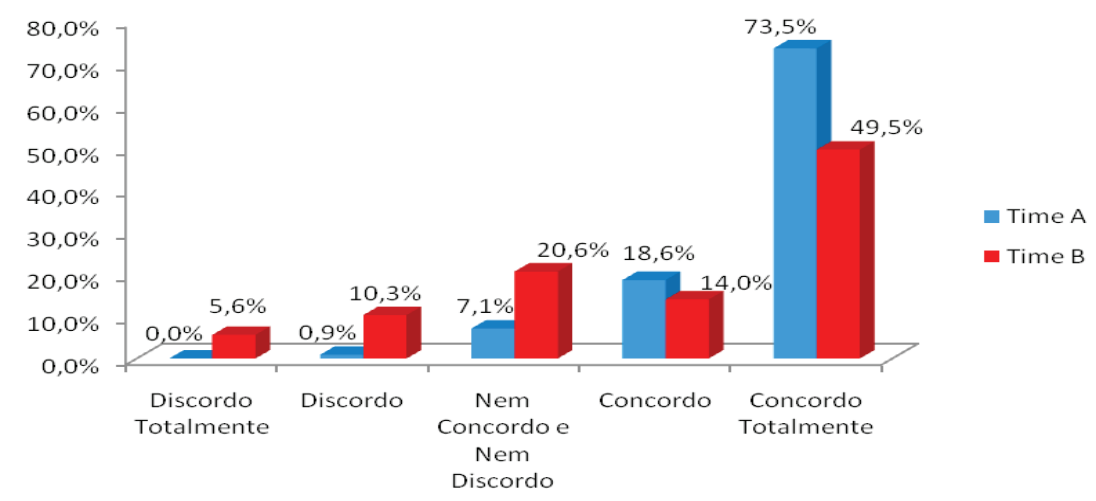

Fonte: Dados da pesquisa.

Uma comparação com os Gráficos 1, 2 e 3, mostra que os torcedores já estão adaptados a realidade da sustentabilidade ambiental e que gostariam de ver seus clubes aderindo também a esta realidade, ou pelo menos divulgando suas ações de sustentabilidade ambiental. Isto converge com a concepção de Dias (2009), para quem o marketing verde implica em considerar novas formas para buscar competitividade para as organizações, atingindo seus objetivos por meio da satisfação das necessidades e do desejo dos consumidores, que acreditam serem importantes para si produtos e processos que respeitem o meio ambiente.

A quarta assertiva, apresentada no Gráfico 4, verificou se o torcedor conhece as ações de sustentabilidade ambiental que seu clube adotou na construção do estádio de seu time.

O Gráfico 4 mostra que a grande maioria dos torcedores do Time A, discordam totalmente $(38,9 \%)$ e discordam $(24,8 \%)$ sobre o tema, com isso, se percebe que a divulgação destas ações de sustentabilidade realizadas pelo clube do Time A na construção do seu estádio são desconhecidas pelos torcedores 
Gráfico 4 - Conheço as ações de sustentabilidade ambiental que meu clube tomou na construção do estádio.

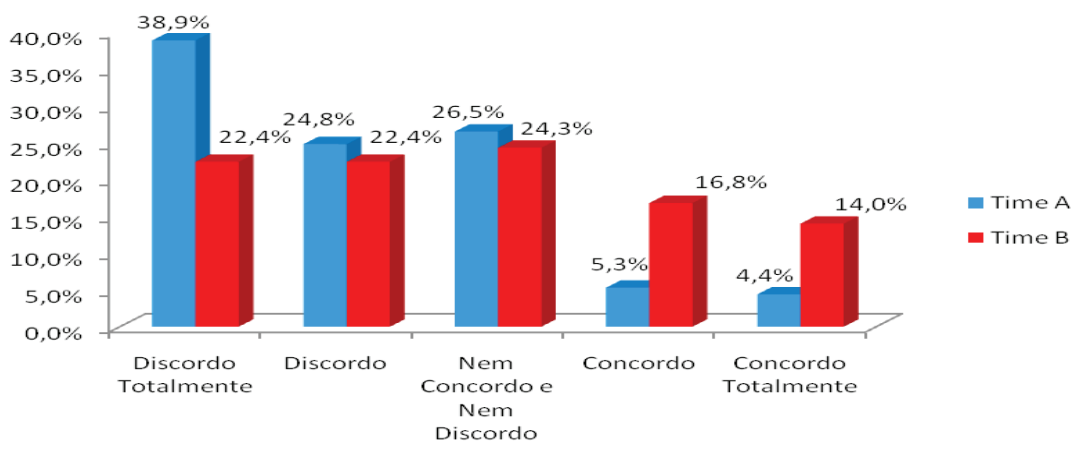

Fonte: Dados da pesquisa

da equipe A. No Time B, as afirmações ficaram equilibradas, com $22,4 \%$ dos torcedores que discordam totalmente, e $22,4 \%$ que discordam, que ao somar, resultam em $44,8 \%$ dos torcedores que discordam e discordam totalmente em relação a afirmação, com $24,3 \%$ nem discordam e nem concordam, e por fim, $16,8 \%$ para os que concordam e $14 \%$ para os que concordam totalmente, a soma resulta em $30,8 \%$ dos que concordam e concordam totalmente em relação a afirmação.

Na percepção dos sócios dos dois times, representada no Gráfico 5, os resultados mostram que 65\% (26 pesquisados) dos sócios do Time A não conhecem as ações ambientais que o clube adotou na construção do estádio.

Já os sócios do Time B, 43,9\% (18) concordam ou concordam totalmente que conhecem as ações ambientais na construção do estádio, 34,2\% discordam e discordam totalmente desta afirmação, e por fim, 22\% dos sócios nem concordam e nem discordam. Com isso, percebe-se que o conhecimento dos sócios do Time A das ações de sustentabilidade ambiental em relação a construção do estádios está muito abaixo do que os sócios do Time B. Neste sentido seria interessante ao 
Gráfico 5 - Conheço as ações de sustentabilidade ambiental que meu clube tomou na construção do estádio na percepção dos sócios.

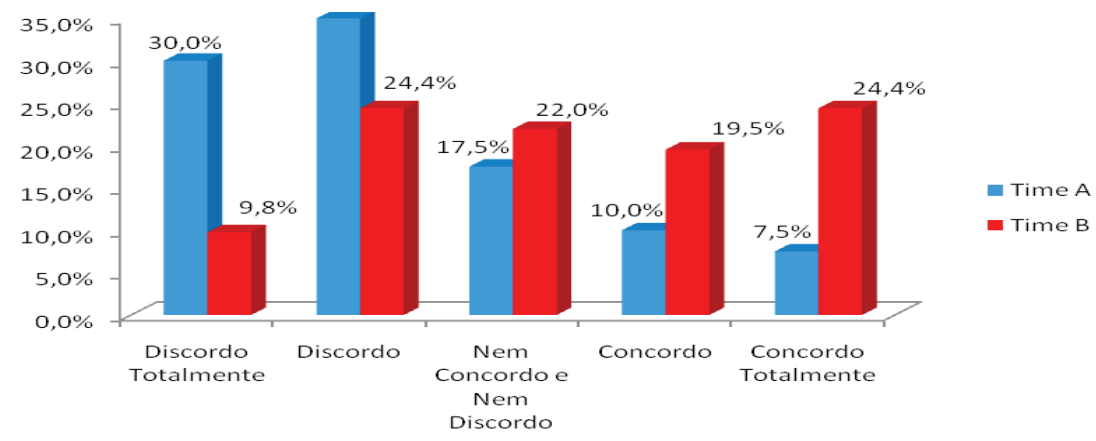

Fonte: Dados da pesquisa.

clube A trazer situações que envolvam as ações ambientais na construção do seu estádio para melhor apresentação ao seus sócios, já que são eles parte fundamental na manutenção do clube de futebol e de duas premissas.

A quinta assertiva, disponível no Gráfico 6, está diretamente relacionada a anterior, onde as repostas permitiram observar que o torcedor acredita que seu clube divulga as ações de sustentabilidade ambiental realizadas no estádio.

Gráfico 6 - Meu clube divulga as ações de sustentabilidade ambiental realizadas no estádio.

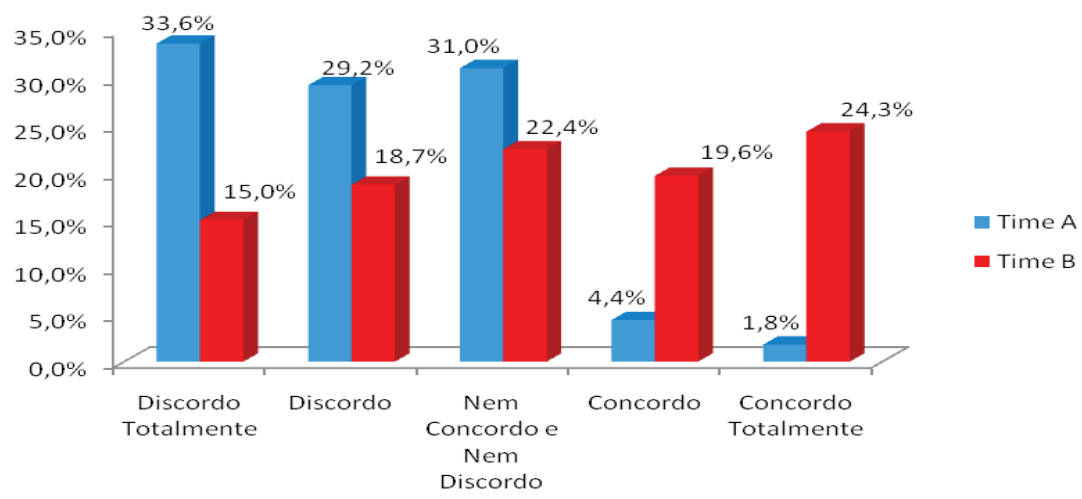

Fonte: Dados da pesquisa. 
Neste pondto, os torcedores do Time A, afirmam que discordam totalmente $(35,5 \%)$ e discordam $(30,8 \%)$ que seu clube divulga as ações de sustentabilidade ambiental realizadas no estádio, ao somá-los, resulta em $66,3 \%$, ou seja, a grande maioria dos torcedores do Time A. No Time B, como já havia sido mostrado no Gráfico 4, as afirmações dos torcedores deste clube ficaram equilibradas, com $38,3 \%$ concordam totalmente e concordam; $23,7 \%$ que discordam totalmente e discordam; e por fim, 22,4\% que são indiferentes a afirmação.

Com as afirmações 4 e 5, percebe-se que tanto o conhecimento do torcedor do Time A e a divulgação das ações de sustentabilidade ambiental por parte do clube A, estão interligadas, resultando em $75,34 \%$, ou seja, a grande maioria destes torcedores afirmaram que não tem conhecimento na divulgação das ações ambinetalmente sustentáveis que foram realizadas na construção do estádio. Já os resultados referentes ao Time B, indicam que $68,63 \%$ dos torcedores concordam e concordam totalmente com as afirmações 4 e 5, ou seja, a grande maioria. Entretanto, há maior relevância por parte do clube B para que seus torcedores tenham conhecimento das ações que o clube tomou na construção do seu estádio, foi melhor divulgado em relação ao Time $\mathrm{A}$, onde se observou esta disparidade.

No Gráfico 7 é apresentada a percepção dos sócios dos dois clubes quanto a assertiva já apresentada para toda a populção pesquisada no Gráfico 6 .

Os sócios do Time A que discordam totalmente 32,5\% e discordam $32,5 \%$, soama $65 \%$ dos pesquisados, confirgurando a grande maioria dos sócios que acreditarem que o seu clube não divulga as ações de sustentabilidade ambiental realizadas no estádio do Time A. Já no Time B, percebe-se que opção concordo totalmente, com $34,1 \%$ das respostas, e concordo com a assertiva, com $14 \%$ respostas, do Gráfico 7 , resulta em $44,1 \%$ das respostas, seguida de $19,5 \%$ que afirmam que nem

ReMas - Revista Metodista de Administração do Sul, v. 2, N. 2, 2017 
Gráfico 7 - Meu clube divulga as ações de sustentabilidade ambiental realizadas no estádio na percepção dos sócios.

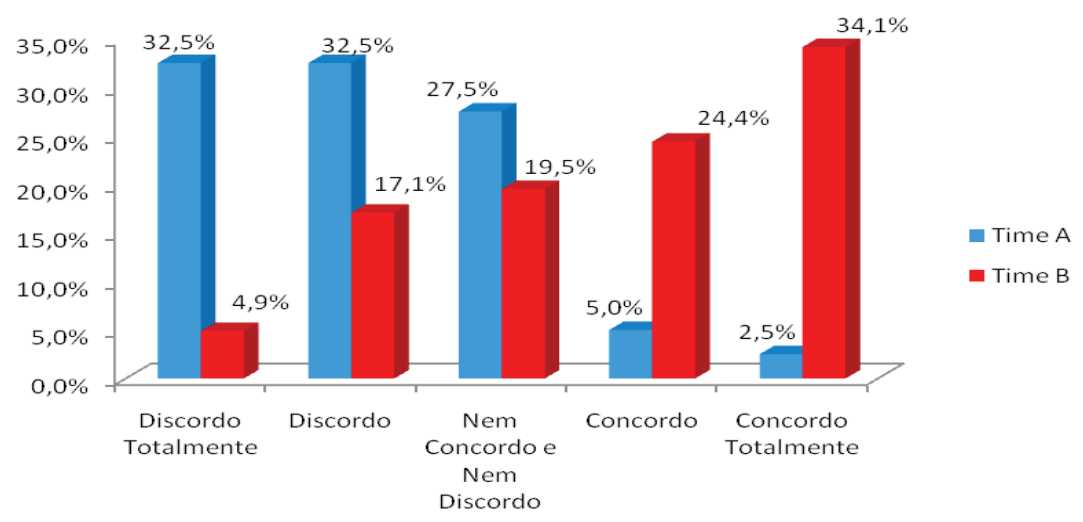

Fonte: Dados da pesquisa.

concordam e nem discordam, e por fim, aqueles que discordam e discordam totalmente, somando $22 \%$ dos pesquisados que são sócios do Time B.

Com isso, se compreende que os sócios do Time B têm uma maior percepção da divulgaçõe das ações de sustentabilidade ambiental realizadas no estádio do que os sócios do Time A.

Para verificar a percepção dos torcedores dos clubes de Porto Alegre se as medidas de sustentabilidade ambiental nos estádios de futebol agregam valor à marca, foi utilizado o mesmo questionário com escala Likert. Para esta etapa da pesquisa foram realizadas duas perguntas. Na primeira, com os dados expostos no Gráfico 8, é apresentada a percepção dos torcedores se a sustentabilidade ambiental no estádio de futebol valoriza a marca do clube. Salienta-se que nesta etapa, como na anterior, as respostas foram analisadas sob dois pontos de vista: a primeira abarca todos os respondentes, a totalidade da amostra; e na segunda são apresentas apenas as respostas dos sócios, que são os torcedores pagantes. 
Gráfico 8 - A sustentabilidade ambiental no estádio de futebol valoriza a marca do clube.

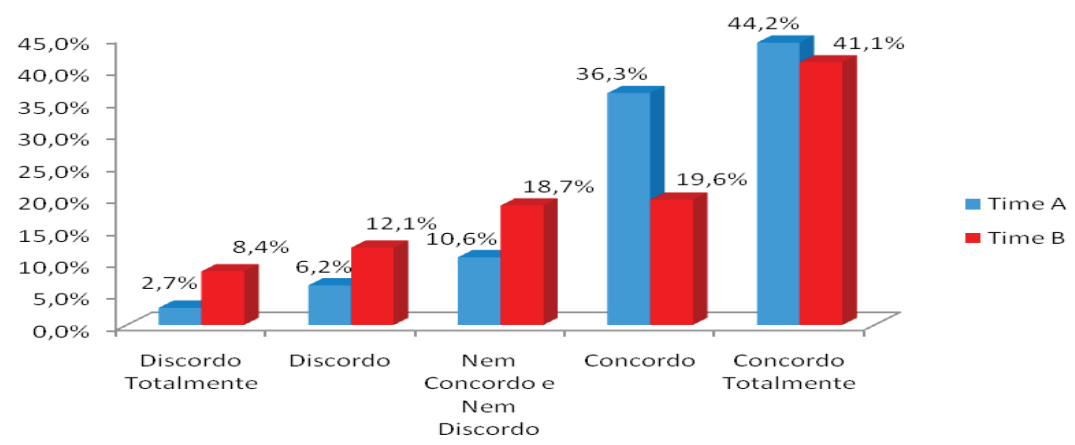

Fonte: Dados da pesquisa.

Na percepção dos sócios, que para o clube são os torcedores que pagam mensalamente para a manutenção do mesmo no mercado e nas competições, são apresentados no Gráfico 9.

Gráfico 9 - sustentabilidade ambiental no estádio de futebol valoriza a marca do clube na percepção dos sócios.

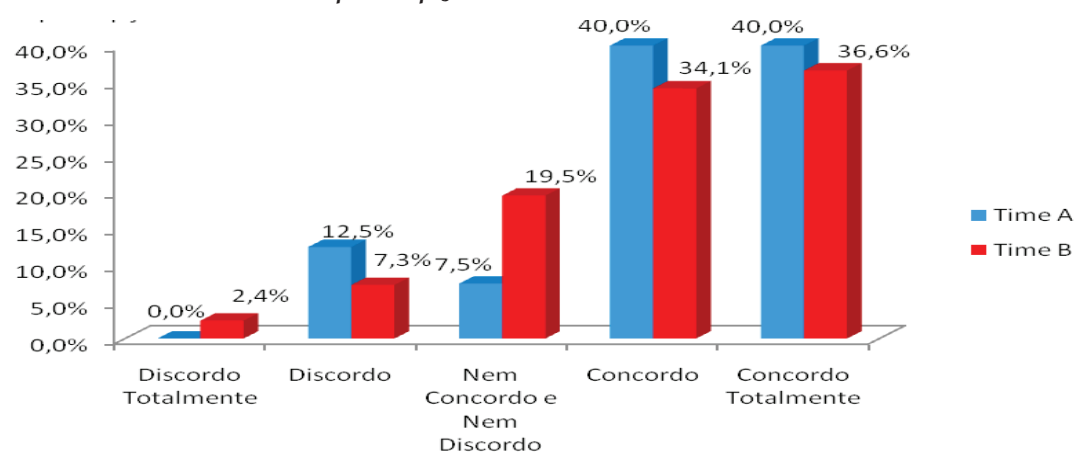

Fonte: Dados da pesquisa.

O Gráfico 9 mostra que, $40 \%$ dos sócios do Time A concordam totalmente e $40 \%$ concordam com a assertiva, somando $80 \%$ dos sócios que acreditam que a sustentabilidade ambiental no estádio de futebol valoriza a marca do clube. Com relação 
aos sócios do clube $B$, se observa que de froma semelhante, a grande maioria, 70,7\% dos sócios concorda ou concorda totalmente com a afirmação, sendo que $36,6 \%$ concorda totalmente e $34,1 \%$ concorda. Com isso é possível verificar que tanto os torcedores no geral quanto os sócios dos clubes A e B, acreditam que a sustentabilidade ambiental dos estádios de futebol agregam valor à marca do seu time.

Neste ponto se destaca opinião de Malagrino (2011) que afirma que a partir da sustentabilidade se pode desenvolver ferramentas de equilíbrio, de ação, de certificação e de indicadores que realmente não falseiam as informações, mas que apresentem a realidade atras das marcas, valorizando-as.

Na continuidade da pesquisa, se observa o Gráfico 10, que apresenta os resultados frente a assertiva "Sei que a FIFA exige certificados sustentáveis nos grandes eventos". Neste quesito $41,6 \%$ dos pesquisados do Time A discordam e discordam totalmente representando, seguidos de $32,7 \%$ que concordam e concordam totalmente com a afirmação. Uma parcela de $25,7 \%$ é indiferente.

Já o Time B têm 40,2\% dos torcedores que afirmam que concordam e concordam totalmente em relação ao tema, 32,8\% discordam e discordam totalmente e $27,1 \%$ são indiferentes.

Comparando os torcedores dos dois clubes, o clube B tem $40,2 \%$ dos pesquisados que disseram concordar com a afirmação, superando os torcedores do clube A.

Na percepção dos sócios, exposta no Gráfico 11, fica claro que $45 \%$ dos torcedores do clube A discordam e discordam totalmente em relação a afirmação de se eles sabem que a FIFA exige certificados sustentáveis nos estádios para grandes eventos; $37,5 \%$ dos sócios concordam e concordam totalmente com a assertiva e 17,5\% são indiferentes. 
Gráfico 10 - Sei que a FIFA exige certificados sustentáveis nos grandes eventos.

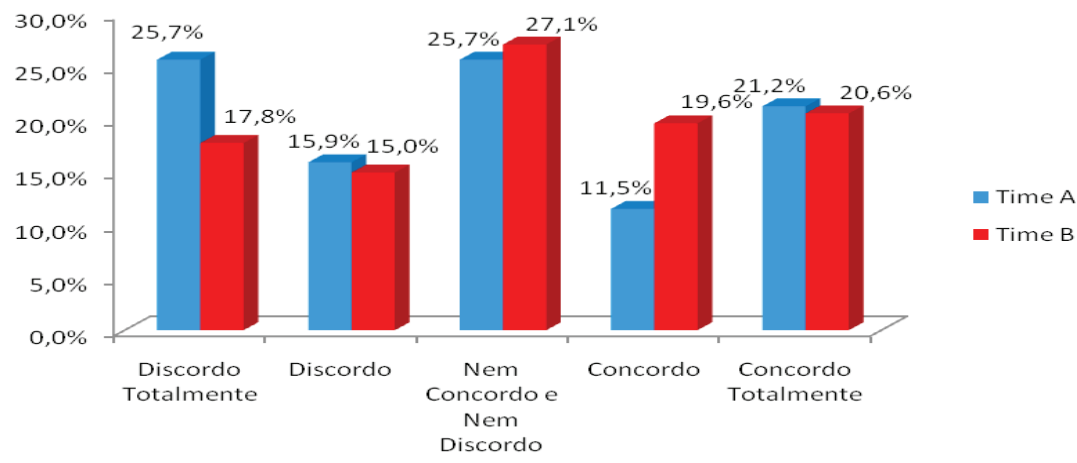

Fonte: Dados da pesquisa.

Gráfico 11 - Sei que a FIFA exige certificados sustentáveis nos grandes eventos na percepção dos sócios.

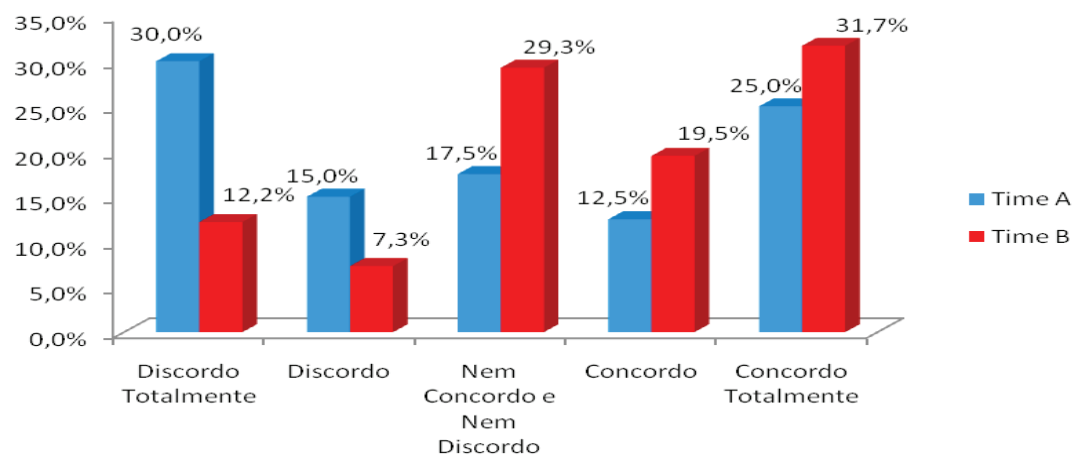

Fonte: Dados da pesquisa.

Com relação ao Time B, frente a mesma assertiva, apresentou $51,2 \%$, que concordam e concordam totalmente com a afirmação, seguidos de $29,3 \%$ são indiferentes, e por fim, $19,5 \%$ que discordam totalmente e discordam. Com isso, se percebe que os sócios do clube B têm maior percepção quanto à afirmação em relação aos sócios do clube A. Verifica-se que 
ainda não é uma preocupação por parte dos clubes de futebol em divulgar os certificados sustentáveis ambientais que o seu estádio possui aos seus torcedores, que recebeu na sua construção/reforma.

Apesar disto é importante ressaltar que a preocupação com o bom desempenho ambiental das organizações, sejam elas quaisquer, inclusive as agremiações esportivas, tem no nome da marca os seus ativos mais valiosos de acordo com Keller e Machado (2006). Neste século é impossível ignorar que a sustentabilidade e as boas práticas ambientais já deixaram de ser um diferencial para ser um fator de exclusão ou enfraquecimento no mercado para as empresas que as ignorarem.

\section{CONSIDERAÇÕES FINAIS}

Quanto aos resultados da pesquisa, estes torcedores se caracterizaram por não serem sócios dos clubes de Porto Alegre, terem idade entre 21 a 30 anos, possuem ensino superior incompleto, e por fim, residem em Porto Alegre.

Quanto ao primeiro objetivo específico se observou que os dois clubes de futebol desenvolvem ações de sustentabilidade ambiental, amplos reaproveita a água da chuva e utilizam lâmpadas que reduzem o consumo de energia, bem como promovem algum tipo de reaproveitamento ou redução de resíduos e melhorias no entorno. O Time A se destacou por utilizar aço reciclado em sua construção e pela recomposição do terreno degradado, permitindo a plantação do gramado. O Time A se destacou pela cobertura em Teflon, durável, reciclado e com aproveitamento da iluminação e refrigeração natural. tem também um estacionamento que privilegia carros pouco poluentes.

Com relação ao segundo objetivo específico, que foi verificar a percepção de um grupo de torcedores sobre as ações de sustentabilidade ambiental desenvolvidas em dois estádios 
de futebol de Porto Alegre, se concluiu que a maioria sequer percebe estas ações, mas a ideia agrada a grande parte dos torcedores. As ações já desenvolvidas e descrita no primeiro objetivo específico são ignoradas pelos torcedores, apenas um grupo de sócios do Time B tem consciência disto. Com relação a divulgação desta ações, no Time A elas são melhor percebidas em relação ao time $B$, tanto entre os torcedores como entre os sócios.

O terceiro objetivo específico, que buscou identificar se as ações de sustentabilidade ambiental agregam valor a marca do clube na percepção dos torcedores dos dois principais clubes de Porto Alegre, se observou que tanto os torcedores como os sócios acreditam que sim, mas a maioria desconhece as exigências da FIFA com relação as certificações ambientais para as edificações que sediam jogos em eventos internacionais.

Como sugestão para a continuidade de pesquisa se sugere um tratamento mais detalhado dos dados em busca de correlações mais elaboradas, que não foram possíveis de serem feitas em função do tempo disponível.

Como limitação se aponta o número de respondentes, que não alcançou o esperado e a impossibilidade dos gestores em receber o pesquisador.

\section{REFERÊNCIAS}

AAKER, D. A. Marcas brand equity: gerenciando o valor da marca. São Paulo: Negócio Editora, 1998.

BOONE, L. E. KURTZ, D. L. Contemporary Marketing. Orlando: The Dryden Press, 2001.

CERTIFICAÇÃO INTERNACIONAL LEED. Certificação LEED. Disponível em: < http://www.gbcbrasil.org.br/?p=certificacao. Acesso em: 06 mai. 2017.

CHATAIGNIER, R. S. Marketing esportivo - teoria e prática: Estudo de caso do clube Atlético Paranaense. Rio de Janeiro: 2004. Disponível em: http://bibliotecadigital.fgv.br/dspace/bitstream/handle/10438/3523/1409393. pdf? sequence=1. Acesso em: 13 nov. 2016.

ReMAS • Revista Metodista de Administração do Sul, v. 2, N. 2, 2017 
DIAS, R. Marketing Ambiental: ética, responsabilidade social e competitividade nos negócios. São Paulo: Atlas, 2009.

DIAS, R. Sustentabilidade: Origem e Fundamentos, Educação e Governança Global, Modelo de Desenvolvimento. São Paulo: Atlas, 2015. 248 p.

FIFA - FÉDÉRATION INTERNATIONALE DE FOOTBALL ASSOCIATION. Football Stadiums - Technical Recommendations and Requirements. Zürich, Switzerland: FIFA, 4th Edition, 2007. 248 p.

GIL, A. C. Métodos e Técnicas de Pesquisa Social. São Paulo: Atlas. Disponível em: https://ayanrafael.files.wordpress.com/2011/08/gil-a-c-mc3a9todos-e-tc3a9cnicas-de-pesquisa-social.pdf. Acesso em: 30 mai 2017.

GUIMARÃES, C. V, COSTA, P. H. Os desafios da Consciência Ambiental: o marketing verde em questão. Ilhéus: C@LEA. Disponível em: http://www. uesc.br/revistas/calea/edicoes/rev4_artigo7.pdf. Acesso em: 16 nov. 2017.

KELLER, K L. MACHADO, M. Gestão Estratégica de Marcas: São Paulo: Pearson, 2006.

KOTLER, P. GERTNER, D. O Marketing Estratégico de Lugares. São Paulo: Revista HSM Management, 2004.

KOTLER, P. KELLER, K L. Administração de Marketing: 12. ed.. São Paulo: Pearson, 2006.

LIKERT, R. Una Técnica para la Medicion de Actitudes. Buenos Aires: Nueva Vision, 1976.

MARCONI, M de A. LAKATOS, E M. Fundamento de Metodologia Científica: 7. ed. São Paulo: Atlas, 2010.

MASCARENHAS, G.; BIENENSTEIN, G.; SÁNCHEZ, F. O Jogo Continua: Megaeventos Esportivos e Cidades. Rio de Janeiro: EdUERJ. 2011.

PEREIRA, R P. Sustentabilidade em Estádios de Futebol: o caso da Arena Pantanal em Cuiabá-MT. Cuiabá: 2013. Disponível em: http://200.129.241.80/ ppgeea/sistema/dissertacoes/17.pdf. Acesso em: 15 out. 2016.

PITTS, B G. STOTLAR, D K. Fundamentos de Marketing Esportivo. São Paulo: Phorte, 2002.

POIT, D R. Organização de Eventos Esportivos. São Paulo: Phorte, 2006.

SINCICH, McClave B. Estatística para Administração e Economia. 10. ed. São Paulo: Pearson Prentice Hall, 2009. 
SUSTENTABILIDADE AMBIENTAL EM ESTÁDIOS DE FUTEBOL:

A PERCEPÇÃO DO TORCEDOR

SOLTO, S K. Marketing 3.0: Um Novo Conceito para Interagir com Um Novo Consumidor. In: Signos do Consumo - v.3, n.2, 2011. 243-245 p.

TEODORO, N F G. Contribuição para a Sustentabilidade na Construção Civil: Reciclagem e Reutilização de Materiais. 2011. 91f. Dissertação (Mestrado) - Universidade Técnica de Lisboa, Lisboa, 2011. 